\title{
Challenges Faced By The Media In Reportage Of Terrorism Activities In Mandera County - Kenya
}

\author{
Obwogi Cliff Ooga \\ Department of Peace and Conflict Studies, P.O Box 8271-00200 Nairobi - Kenya \\ DOI: 10.29322/IJSRP.10.10.2020.p10658 \\ http://dx.doi.org/10.29322/IJSRP.10.10.2020.p10658
}

\begin{abstract}
The media both National and International face a myriad challenges as they grapple with the news whose subject matter is terrorism. There is a need for news stories which sell well to the population vis-à-vis the challenge of how much and in what manner should such news be broadcasted to the public. The media in one way or the other have ended up advancing the agenda being pursued by the terrorists knowingly and sometimes unknowingly. The media want profits from the news they report and so sometimes they through caution to the wind and aid the terrorists in their achieving of the agenda of sustained exposure or publicity in the media. Moreover, media in the process of news gathering face a number of challenges as it will be discussed in this paper. The objective of this study was to examine the challenges faced by media in reportage of terrorism activities in Mandera County. It was established that most of the media broadcasts relating to terrorism journalism were war or violence oriented and to a greater extent, media content opposed efforts aimed at fighting terrorism. The resultant effects included radicalization and youth recruitment into Al-Shabaab, poor infrastructural development, and increased hatred for Security Agencies. The study was motivated by the need to inform the drafting of new policies and guidelines and the redrafting of existing policies regarding to the broadcast of terrorism activities.
\end{abstract}

Index Terms- Reportage of Terrorism, Challenges, Media

\section{INTRODUCTION}

$\mathrm{T}$ he media are alive to the fact that, they will encounter challenges while undertaking their duties of news gathering. These challenges vary from one set up to the other depending on how that particular community is endowed with resources which may be organic or inorganic. The Citizens usually may not be privy to the challenges the media go through to present news in time. They audience is always in need of timely, accurate and interesting news.

McQuail (1987) argues that there is evidence which postulates that the population or citizens have a tendency to think about issues they listen or watch in the media. The challenges and dilemmas that come out as a result of this are usually clear to everyone. Audiences expect the press to inform them as accurately and consistently as possible without sensationalizing the news.

Whilst analyzing the ideal situation in relation to the actual situation, one will get to an understanding that presenting terrorism in a manner that clearly rejects violence, demystifies assassins and emphasizes victims' personal tragedies is an essential resource in any type of multi-pronged strategy that combats terror. However, a problem comes up when media gets controlled by certain ideological, cultural or religious conniving thereby beginning to look for an imagined balance between murderers and victims; when the causes being championed by certain terrorist groups are justified against others; or when a story is treated in such a way that it gives the viewer the impression that terrorist groups are political participants that deserve certain legitimacy in the competition for power. Past research studies indicate that the media is a vital component for the terrorists to perpetuate and spread fear onto large audiences than the small group of victims of a terrorist act. It is a special means of attracting and maintaining the audience's attention and consequently passing over the messages of the terrorists group.

A question arises on what the responsibility of journalists would be when they supply the oxygen of publicity to terrorists. Any form of journalism which engages itself in reporting, analyzing and commenting on terrorism is faced with a challenge of creating responsible, intelligible and accurate narratives about terrorism. Journalists also face enormous challenges which relate to the wider practices of journalism especially when it comes to matters to do with breaking news and generally conflict journalism (Rodgers, 2012).

The world stares at a challenge of sensational reporting of terrorist news in a simplistic way and in a rush thus rendering the role of professional journalism irrelevant and diminished. The news on terrorism in a click of a button are digitally available raw with no regard for professional journalistic ethics courtesy of the digital platforms. For the first time in the year 2016 the month of February, the government of the US invited social media executives to help in generating ideas on how to counter terrorists' use of the internet to broadcast their messages. A number of Executives who attended came from Facebook, Snapcht, Tumblr, and Google. Twitter, Instagram and Microsoft attended the forum (New York Times, 2016).

The world's concern is that the media are involved in the broadcast of news on terrorism in such a way that the news spread fear and confusion among the viewers or readers as well as listeners. Journalists struggle to catch up with the fast revolving wheel of terrorism. The fast revolving cycle of terrorism news is fast and often complex. This is more complicated especially when it comes to reporting on breaking news where journalists have to contend with the speed and complexity of the way information flow which is usually dictated by government authorities, the social media practitioners and even the terrorists themselves (Beckett, 2016). 


\section{LITERATURE REVIEW}

It should be clear to everyone concerned that in the United States of America, faith in American press has plunged to its new low. At such moment in time when the press is faced with enormous economic challenges, we must work tirelessly towards rebuilding the public's confidence in the media. The audiences have so many options to access news and so many disruptions from journalism. Terrorists know how to put to test all systems of government and public ones. Improving reportage on terrorism is vital because these extremist activities are prominent matters of concern and results into enormous challenges around the globe. The need to have in place informed, trained and skillful human resources able to report judiciously on terrorism is crucial. This is not just a moral appeal but a requirement and a necessity. It is an opportunity to showcase to the world that journalism is and it retains the central spot it occupies in the modern society (Beckett, (2016).

Omoera and Ake (2016) conducted a study on extremists' violence and how the media faces enormous challenges while undertaking the task of reporting on terrorism activities in Nigeria. Reporting terrorism or extremists' violence poses a host of difficulties and dilemmas for media experts, data managers and other state actors who are charged with the duties of delivering data objectively, responsibly, and appropriately to guarantee efficient communication of growth in society.

Similarly, insurgent or terrorist groups are spreading their excessive causes, transmitting their radicalization messages, and gaining popular assistance, recognition, and legitimacy through media channels like handbills, internet, radio, and film. Media or media experts in terror acts have accidentally become accomplices or victims or threatened species. Nevertheless, they are obliged to report the events irrespective of the consequences for the audience. Indeed, it was asserted that the sensational reporting and excessive dramatization of the media operations of extremist groups propagates further terrorist acts (Omoera \& Ake, 2016).

Pressure which is often directed onto the media to broadcast news which is premised on terrorism does not necessarily mean that the terrorist organizations have taken total control on the media. However, it does indicate that there is always an obligation for the press to remain constantly seized by the moment to discern and refuse the manipulation of terrorists. As much as the audience pressures the media to reveal sensitive information, the media has to know the limits of the type of information to release to the public so as not to be part of propping the terrorists' agenda (Wilkinson, 1997).

Martin (2010) remarked that there exists in the world a commonly referenced quote that the person who has information has the power. Therefore, the audience needs the information to be in the position of being able to know what is happening around them. Terror attacks are often instigated on the innocent civilians so that the terrorists are able to attract media attention who will report on their heinous acts thereby drawing the audience's attention and sustaining it. Media are ever working hard to resonate well with their audiences. Television stations work extra hard through presenting sensational news so as to attract as many viewers as possible, newspapers work hard towards attracting their target audience and websites try to attract visitors onto their websites through presenting dramatic news.
Perspective from which a story is reported is significant to both the viewers and the terrorist organizations. Those in the media industry should prudently utilize the limited time they have at their disposal to asses and determine what kind of news stories to disseminate and in what manner it should be published. The highly sensitive news which the population might find upsetting is crucial that the editors give a sober and rational interpretation of the facts. Personal biases on terrorism matters are under the personal influence of the editor whom their cultural, political and personal biases are reflected in the news they present to their audiences (Martin, 2010).

Media has to sacrifice on providing the breaking news aspect on the basis that they have to broadcast well researched news based on facts. The media has to substitute the breaking news with factual news. Therefore the element of prompt news or immediate news has to be sacrificed at the expense of factually established news. The hurry to publish news often will elicit unnecessary fear in the public while at the same time encouraging more terrorist attacks through the sustained media coverage which the terrorists desperately crave for (Martin, 2010). The media ought to take to account the obligation they have in responsibly accurately informing citizens regarding activities on terrorism whenever they occur.

Mark Blaise is a renowned Dutch critic of the media who believes that the media have become predisposed to immense pressure from the environment and this pressure tends to suppress objective and accurate reporting. He further suggests that the main driving objective of their reporting is the creation of more profits. All the media is looking for in their quest to inform is creation of profits through mobilizing audience viewership and readership (Blaisse, 1992).

Blaisse (1992) once retorted that if one has enough finances, he/she will be capable of buying all the newspapers, radio stations and TV stations they want. Media concentrates its coverage on the predominant form of terrorism in that period of time. For instance, from about the 1960 s to the 1980 s, the news broadcasted covered mainly the extreme right and left and preindependence political movements. As much as the right and left extremists terrorism has not completely disappeared, currently though the media focuses much on religiously-inspired terrorism since it attracts bid audiences. This kind of media coverage is usually aimed at reporting on instigated by organizations claiming to follow Islam, which generates the widest media coverage.

The manner in which terrorist news are reported has immense effects on the future of terrorist actions, the way governments will react once an attack has happened and the general public's opinion. Journalists' way of reporting constitutes description of the violence as witnessed in the terror activities, how they are emphasized, how they are structured or formulated and how unique these activities indeed are. It is from this arising scenario that we can make conclusions that there is a critical relationship which the media complements between the terrorists, states/Government administrations and the public in general (Paletz \& Tawney, 1992).

Global media, including the African media, is confronted with serious challenges of how to disseminate terror messages without aiding terror acts/terrorists or being victims. It is in this connection that we examine some of the challenges the African 
media professionals face and some strategies to remediate them (Iqbal, (2015).

\section{METHODOLOGY}

This paper adopted a descriptive research design. Descriptive research is directed at making careful observations and detailed documentation of a phenomenon of interest. These observations must be based on the scientific method and therefore, are more reliable. The study was carried out in Mandera County. Mandera County is found in the former North Eastern Province of Kenya. Its capital and largest town is Mandera town. The county has a population of about 867,457 (2019 census) and an area of $25,797.7 \mathrm{~km}^{2}$.

The study population included both residents and nonresidents in Mandera County. The target population constituted Mandera County Officials, the NPS personnel, KDF personnel, media personnel (both local and international media representatives in Mandera County), NIS personnel as well as officials from NGOs, FBOs and CBOs. Simple random sampling was used to obtain respondents from within the general population of Mandera County. Purposive sampling was used to obtain key informants from the population of officials from Mandera County Government, the NPS personnel in Mandera County, KDF personnel, local and international media representatives in Mandera County, NIS personnel and officials from NGOs, FBOs as well as CBOs within Mandera County. A sample size of 384 was calculated using a formula proposed by Fisher (1998) which is: $\mathbf{n}=\mathbf{z}^{2} \mathbf{p q}$

\section{$\mathbf{d}^{2}$}

The study used mix method technique in data collection where both primary and secondary data were collected. The research instruments for primary data collection were questionnaires while secondary data was obtained by use of key informant interviews and FGDs. The interview schedule, FGDs and questionnaires were developed with special focus on achieving the research objective. Questionnaires with both closed and open ended questions were used in this study. The interviews conducted in this study were key informant interviews where the respondents were selected purposively. Information from key informants was obtained through inquiry and recorded by researchers. Structured interviews were performed by use of open interviews; the researcher taking notes while talking with respondents.

To ensure validity and reliability of the research instruments, the researcher conducted a pilot study in the following places: Elwak, Lafey, Fino and Omar Jillo prior to the actual data collection. All resulting discrepancies were corrected to ensure that the results remain the same as if the research was to be repeated under similar circumstances. The study also made use of the supervisors and MMUST Research Experts who ensured that the research instruments were valid and reliable.

The researcher used mixed (qualitative and quantitative) approaches of data analysis to provide the researcher with an ideal method needed for descriptive explanation. Quantitative data underwent the process of data management. Thereafter, the data was coded and entered into a computer software programStatistical Packages for Social Sciences (SPSS) for analysis.
Qualitative data was analyzed using summary sheet by compiling specific phrases and key words used by respondents in description of scenarios to represent themes. The researcher used short abbreviations as descriptive codes to label data, usually a comment from key informants, under an appropriate category such as numeric codes are organized around relevant ideas, concepts, questions, or themes. Similarities and differences were sorted out then merged into larger categories then further into sub-themes. The results were presented in form of tables, charts and graphs.

\section{STUDY FindINGS}

The study established that there were challenges faced by the media in their reportage of terrorism. This was as noted by $78 \%$ (222) of the respondents with $22 \%$ (62) noting that there were no challenges faced by the media in their reportage of terrorism.

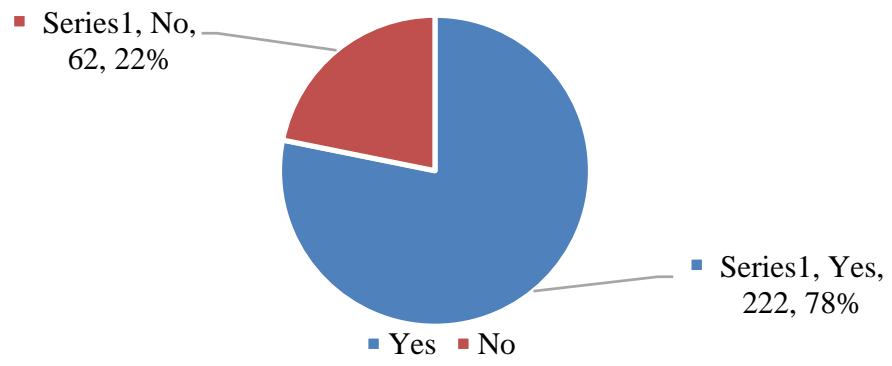

The following were the major challenges which were noted: conflict of interest, poor communications network, myths on terrorism, lack of mutual trust, fear and intimidation, pressure and coercion and will be elaborated.

\subsection{Conflict of interest}

Lack of balance between objectivity and accuracy against the need to make stories and reports that sell was also cited as a challenge within the media circles.

Press pundits have over time questioned if media practices objectivity in its quest to inform the public and thus, a challenge to media reportage of terrorist activities. This challenge has been exacerbated by the pressure on the media to report terror activities which suppresses objectivity and accuracy. It is usually noted that, journalists tend to pre-conclude situations and give personal opinions on issues with a view of meeting deadlines for going to press or going on air and thus, the information reported is most likely subjective. This is as a result of the pressure under which they work to deliver news promptly for a better sale. Therefore this comes into conflict with the quality of news to be presented.

Both the print and electronic media covered extensively the heinous assaults which were visited on the Westgate mall, attacks in Mandera County, assault on Mpeketoni in Lamu County and the Garissa university assault in Garissa County. Both Kenyan and international press were awash with photos exhibiting grueling pain which the survivors were going through. Others broadcasted raw photos showing physical injuries and several deaths in cold blood. It is the presence of these media outlets that hampers the strong efforts put in place by the Kenyan Government to control damage and safeguard the integrity of the rescue operations and 
also coordinate on the methodology to be employed when reporting on these acts of terror. It is such type of circumstances where media inadvertently offers an opportunity for Al-Shabaab to display their attacks with little if any censorship and also exploit such circumstances to spread their propaganda. Therefore the media unknowingly grants them the oxygen to survive as well as thrive (Jacobs, 2012). This is a conflict of interest between the rights of the public to be informed vis-à-vis the national security interests.

Another instance in conflict of interest is when the public needs to know what is happening in the terrorists' world at the expense of the country's economic development. This observation is well captured in Gagalo's publication whereby it takes note that several reasons have been put forth as to why Al-Shabaab is hell bent on attacking Kenya and not other neighbours. Among the reasons given is that Al-Shabaab wants to sabotage the Kenyan economy, another reason being that Al-Shabaab wants to influence the Kenyan foreign policy by forcing the withdraw of KDF troops from Somalia. These reasons could be true but it is important to consider the bigger picture of Kenya being a tourist hub in the region and this grants the terrorists opportunity to attack these tourists. This comes about with a lot of media coverage which keeps Al-Shabaab in the visibility so as to remain relevant in the international stage. The associated media coverage and damage done to Kenya's image and economy also bleeds into AlShabaab's pursuit for survival and equally global and regional publicity (Galgalo, 2015).

\subsection{Poor communications network}

Poor facilities such as road network, transport and communication have been a painstaking limitation for journalists when gathering information in the field. Poor road networks and inadequate means of transport have made it impossible for journalists to travel and meet informants. The unreliable communication system available has made it difficult not only to obtain information but also to verify the authenticity of the information provided.

\subsection{Myths on Terrorism}

The myths and misconceptions surrounding the whole subject of terrorism make it difficult to obtain and verify information. Journalists who were enjoined in the study noted that because of the myths and misconceptions surrounding the issue of terrorism, it has become difficult to authenticate or verify information especially in cases where the sources of information are from different cultural and ideological backgrounds. For instance, while some myths assert that terrorism is associated with Islam and all Muslims, informants who are non-Muslims would readily give information that is biased against the Muslim community. This challenge is aggravated by the lack of means of verifying information obtained from their sources.

It is common knowledge that security officers hold classified information meaning that the information is sensitive and so it is important for them to maintain a close and warm working relationship with the media to avoid improper disclosure of information which may cause harm, injure or damage to the country's reputation. On the other hand, the journalists ought to understand the procedures for information disclosure by the security officers and whoever is authorize to give information.
Therefore, it follows that information should be utilized responsibly and with care without compromising the lives of the officers, journalists, victims, survivors or an ongoing operation (Media Council of Kenya \& International Media Support, 2016).

\subsection{Lack of Mutual trust}

There are suspicions amongst these institutions developing, and implementing or carrying out anti-terrorism strategies. Despite this, the Kenya Defense Forces tends to be a bit more organized and robust in terms of information sharing and their relationship with the media more than the National Police Service who most times are not comfortable with the media (Media Council of Kenya \& International Media Support, 2016).

It is important to be cognizant of the fact that the police and the media can co-exist while performing two similar yet so different roles - the key is to develop a strong relationship prior to critical incident. The two institutions should learn to work together in peace time such that when an incident occurs they will be able to harmoniously carry on with their tasks. Both sides have to be enlightened so that they are well versed with the policies of their counterpart and perhaps most importantly is that both sides have to respect the policies in place which they will work around (Media Council of Kenya \& International Media Support, 2016). The police/military and media should endeavour to conduct regular meetings between so as to create a synergy of working together. In the process they develop rules and regulations or procedures which will assist them work together successfully without infringing on one another's rights. They should also conduct joint training classes which will also greatly help in bridging the gap of mutual suspicions between the security forces and the media. Improved media and security forces working networks and sessions are vital as they can help improve information flow and build on mutual trust. The police can also assist in bridging the relationship gap by being a bit more open with the media. Regular, consistent and credible information sharing on the process and stages of security operations can help improve or create healthy working relationships and improve access to information or volunteering of information by security forces which will translate into responsible reportage (Media Council of Kenya \& International Media Support, 2016).

\subsection{Fear and Intimidation}

Fear of being attacked and hurt by terrorists as well as intimidation and blackmail by terrorists and sources of information was further cited as a limitation to media reportage. Serious professional journalism is difficult work at the best of times. In a society threatened by terrorism and/or violent extremism, journalists face much greater difficulties and will likely operate in a climate of fear and threats. The spread of propaganda and unverified information on social media sometimes works against facts presented by journalists. In the current times where information flows very quickly in the digital world, journalists have had the challenge of countering falsehood, propaganda and unverified information shared on social media and blogs by unverified sources. This has placed media houses at the center of confusion trying to clear the air on what are the real facts and what is unverified.

Further in understanding the challenges faced by the media in reportage of terrorists' activities, the study interrogated the 
position of terrorists in the media. The study established that $67 \%$ of the respondents felt that terrorists have projected themselves better in the media than the government. The study noted that with the day-in day-out coverage of terrorist activities in the media is a depiction of terrorists projecting their presence better than the government through the media. Key informants in the study were further in agreement with these sentiments, most of who noted that terrorists have mastered the art of strategically positioning themselves well in their media to justify their acts and advance their agenda. Their resounding sentiments further paint a picture of a media that gives much airtime to terrorists and terrorism in general.

The media has on a number of occasions been seen to play an accomplice to the success of these acts of terror. This has been witnessed more so during the processes of reporting and covering these acts of terror whenever and wherever they take place. Their coverage intentionally or unintentionally gives so much publicity to the terrorist groups; a mileage they really crave to achieve.

The example of the September 11, 2001, attacks were sufficiently visual to meet the demands of the TV culture and to satisfy the public fascination for live coverage of events. By attacking cities like New York, among others, where the largest concentration of television stations and film studios and equipment exist, terrorists not only guaranteed for themselves an exhaustive coverage and a global projection of their actions, but the existence of multiple tourists and citizens who had their own film equipment. This allowed news broadcasters to utilize domestically filmed new materials in which the news did not have as much to do with the terrorist attack as with the existence of new images that allowed the viewing public to contemplate the horror and destruction from a different point of view.

Dramatic incidents, stories with emotional aspects, and negative news stories are the topics that readers find interesting. Other kinds of stories that tend to draw high levels of interest are those that are exciting and sensational, and those that directly affect the audience (Glüpker, 2008). News stories that report on terrorists' actions or attacks are a suitable example of stories which satisfy all these characteristics.

Terrorism happen to be very brutal as well as a violent practice but it is also happens to be the global media's spectacular phenomenon which they cannot escape from covering for the sake of improving their viewership which translates to profits. News on terrorism is very juicy and vital: such kinds of news often make the public want to know more and seek for further understanding on what exactly transpired. The news is very dramatic and attractive to watch or read. This is what exactly terrorists look for, the kind of publicity the terrorists get from journalists when covering such kind of news. The media in reporting such news aids the terrorists achieve the effect of disrupting society functioning provoke fear and demonstrate that they are powerful (Beckett, 2016).

\subsection{Pressure and Coercion}

The study further established that the media received a lot of pressure from different quarters to inform on terrorists activities including from terrorists themselves through coercion and threats. The findings of this study are in tandem with Dutch journalist Mark Blaisse who observes that the media have become predisposed to immense pressure from the environment and this pressure tends to suppress objective and accurate reporting. $\mathrm{He}$ further suggests that the main driving objective of their reporting is the creation of more profits. All the media is looking for in their quest to inform is creation of profits through mobilizing audience viewership and readership (Blaisse, 1992).

\section{DISCUSSION}

An analysis of the responses given in by the participants clearly depicts the fact that acts of terror have alienated the youth and even the old from leading a normal life in Mandera County just like the rest of the country. Terrorism has made the County not gain much in development due to investors being scared from investing in the County (Business Daily, 2019).

It is important to reiterate the conflicts that exist between the media and the security agencies when there is a terrorist attack kind of a situation. Due to the long standing suspicions amongst the media and the security agencies that media are out to discredit the security agencies and the security agencies are out to cover up their flaws. This has always been a bone of contention. Such incidents have been experienced in the recent past during the terrorist attacks on Westgate Mall in Nairobi, the attack on the Garissa University, in Lamu County at the border of Kenya and Somali and in Mombasa County several times (Media Council of Kenya and International Media Support, 2016).

In the recent past as experienced in the Westgate Mall attack, the Kenya Defense Forces accused the media of compromising the operation. The media while undertaking a live coverage of the operation indirectly aided the attackers. The media also did jeopardize the lives of the security officers and the victims through life coverage of the military operation revealing the military strategy towards defeating the terrorists and rescuing the victims of the attack (Media Council of Kenya and International Media Support, 2016).

While there are flaws in the way the media cover security undertakings which has contributed to lack of trust in the media from security agents, the tensions and conflicts can also be explained by the lack of understanding amongst security agencies on the role of media play in a democratic society and vice versa. If the media is not accorded the freedom to report then there is a likelihood of letting propaganda flourish. This again can lead to biased media coverage due to the lack of access to information that is provided, as well as direct threats against journalists who run the risk of imprisonment and restrictions of their rights (Media Council of Kenya and International Media Support, 2016).

For the advice of Kenyan media experts, the study would recommend a replication of the European Union Technical Assistance to Nigeria's Evolving Security Challenges (EUTANS) framework for reporting responsibly on violent extremism as part of the effective and preferred approaches to address the challenges of reporting terrorism in Kenya. Journalism involves a high degree of government confidence. To gain and retain this confidence, sticking with the greatest professional and ethical norms is morally imperative for every journalist and news medium. A journalist should always have a good public interest at heart in the practice of these responsibilities. Truth is the cornerstone of journalism, and every journalist has to work diligently to find out the reality of every evening (Okeke \& Odubajo, 2018). 
Gever (2015) stated that a professional journalist should be responsible for decisions on the content of news he or she presents unto the public. The public is entitled to understand the news being broadcasted. Factual, precise, balanced and fair reporting are the ultimate goal of excellent journalism and the foundation for gaining public trust and belief. A reporter should refrain from publishing information that is incorrect and misleading. Should such information be released accidentally, timely correction should be made. As a cardinal rule of practice, a journalist must have the right to answer. A journalist should seek to distinguish facts from assumptions and provide guidance in the course of his or her responsibilities.

A journalist should follow the principle of confidentiality that is widely recognized and should not reveal the source of confidential data. A journalist should not breach an agreement with an off-the-record source of information. In order to suppress or publish data, a journalist should not solicit or accept bribe, gratification or patronage. Requesting payment for news publishing is inimical to the concept of news as an event's fair, precise, unbiased and factual report. A reporter should not present violence, armed robbery, terrorist activity or vulgar wealth display in a way that glorifies such acts in the public's eyes (Bal \& Baruh, 2015).

\section{CONCLUSIONS}

The study concluded that that there were challenges faced by the media in their reportage of terrorism. These challenges made it difficult for the media to gather credible, accurate and verifiable news from the ground. Therefore, media ended up framing news in the way it felt appropriate thereby propelling the terrorists' agenda. The following are the challenges which were established by the study: Conflict of interest, poor communications network, myths on terrorism, lack of mutual trust, fear and intimidation as well as pressure and coercion

\section{RECOMMENDATION}

The study recommends that, stringent measures tailored in understanding media reportage, be adopted .Additionally, the study recommends the establishment of better communication strategies to address the spilling problem of communication network.

\section{REFERENCES}

[1] Bal, H. M., \& Baruh, L. (2015). Citizen involvement in emergency reporting: a study on witnessing and citizen journalism. Interactions: Studies in Communication \& Culture, 6(2), 213-231.

[2] Beckett, C. (2016) Fanning the Flames: Reporting Terror in a Networked World is a professor in the Department of Media and Communications at the London School of Economics. Colombia Journalism School.

[3] Blaisse, M. (1992). Reporters' perspectives. In D.L. Paletz \& C. D. Schmid, Terrorism and the media. (pp.137-169). London: Sage.

[4] Business Daily (2019). Social Research Methods. 3rd ed. Oxford: Oxford University Press. Business Daily (2019) Why Al-Shabaab targets Kenya and what the country can do about it. Available at https://www.businessdailyafrica.com/Why-Al-Shabaab-targets-Kenya-andwhat-the-country-can-do-about-it/

[5] Galgalo B. (2015). "Tourism Industry on the Verge of Collapse, Officials Warn," Daily Nation, Print Edition, April 24, 2015

[6] Gever, V. C. (2015). Comparative Analysis of Public and private Broadcast Media Surveillance of the Boko Haram Insurgency in Nigeria. International Journal of Crisis Management, 5, 22-32.

[7] Glüpker, G. (2008) Media and terrorism. Norderstedt: Germany.

[8] Iqbal, M. Z. (2015). The media-terrorism symbiosis: A case study of Mumbai attacks, 2008. Asian Journal of Communication, 25(2), 197-212.

[9] Jacobs A. (2012). "Pursuing Soft Power, China Puts Stamp on Africa's News," New York Times. August 16, 2012 http://www.nytimes.com/2012/08/17/world/africa/chinas-news-mediamakeinroads-in-africa.html?_r $=0$ (accessed April 6, 2019).

[10] Martin, G. (2010). Understanding terrorism: Challenges, perspectives and issues. London: Sage.

[11] McQuail, D. 1987. Mass communication theory: An introduction. London: SAGE Publications.

[12] Media Council of Kenya (MCK) and International Media Support (IMS) (2016) A handbook on reporting terrorism. International Media Support

[13] New York Times (2016). US asks tech and entertainment industries in fighting terrorism," available at: http://www.nytimes.com/2016/02/25/technology/tech-and-media firmscalled-to-white-house-for-terrorism-meeting.html?_r=0).

[14] Okeke, G. S., \& Odubajo, T. (2018). Regional Economic Groupings and Security Challenges: A Comparative Study of ECOWAS and SADC. Journal of International \& Global Studies, 9(2).

[15] Omoera, O. S. \& Ake, K. O. (2016). Extreme violence and the media: challenges of reporting terrorism in Nigeria. Trans-Humanities Journal, 9(3), 127-146.

[16] Paletz, D. L. \& Tawney, L. L. (1992) Broadcasting organizations' perspectives. In D. L. Paletz \& C. D. Schmid, Terrorism and the Media. (pp. 105-110) London: Sage.

[17] Rodgers $\mathrm{J}$.

(2012) "ReportingConflict,"availableat:https://he.palgrave.com/page/detail/reportin g-conflict-james-rodgers/?sf1=barcode \&st1=9780230274464).

[18] Wilkinson, P. (1997). The media and terrorism: A reassessment. London: Frank Cass

\section{AUTHORS}

First Author - Obwogi Cliff Ooga,Department of Peace and Conflict Studies, P.O Box 8271-00200 Nairobi - Kenya 